d. COLUMBIA |SIPA

Center on Global Economic Governance

CGEG-CDEP WORKING PAPER SERIES

CGEG-CDEP WP No. 12

Legal Corruption, Politically Connected

Corporate Governance and Firm

Performance

Polona Domadenik, Janez Prašnikar and Jan Svejnar

March 2014

dol COLUMBIA |SIPA

Center for Development Economics and Policy 


\title{
Legal Corruption, Politically Connected Corporate Governance and Firm Performance
}

\author{
Polona Domadenik \\ University of Ljubljana \\ Faculty of Economics \\ Janez Prašnikar \\ University of Ljubljana \\ Faculty of Economics \\ Jan Svejnar \\ Columbia University
}

March 2014

Keywords: corruption, corporate governance, productivity, politicians, state owned enterprises

\begin{abstract}
In this paper we present and test a theory of how political corruption, found in many transition and emerging market economies, affects corporate governance and productive efficiency of firms. Our model predicts that underdeveloped democratic institutions that do not punish political corruption result in political connectedness of firms that in turn has a negative effect on performance. We test this prediction on an almost complete population of Slovenian joint stock companies with 100 or more employees. Using the supervisory board structure, together with balance sheet and income statement data for 2000-2010, we show that a higher share of politically connected supervisory board members leads to lower productivity.
\end{abstract}




\section{Introduction}

Why do firms prefer to be politically connected? Researchers have noted that firms try to achieve economic advantages over their competitors in a variety of ways, including a preferential treatment by state-owned banks in obtaining credit, easier access to government contracts, lighter taxation, and more relaxed regulatory environment (Faccio, 2006). Political connectedness has been noted in the seminal papers of Tullock (1967), Stigler (1971) and Krueger (1974), and further documented in more recent studies of developed economies (e.g., Agrawal and Knoeber, 2001, and Krozsner and Stratmann, 1998, for USA) as well as developing and transition economies (e.g., Fisman, 2001, for Indonesia, Khwaja and Mian, 2005, for Pakistan, Kang, 2003, for China, Johnston and Mitton, 2003, for Malaysia, Dombrovsky, 2008, for Latvia, and Vynoslavaska et al., 2005, for Russia and Ukraine).

The relationship between corruption and economic performance has been a focus of attention ever since Olson (1982) argued that special interest groups could cause stagnation and decline of nations. Shleifer and Vishny (1993) developed the argument that corruption is a destructive force in developing countries with weak institutions, and political connectedness of firms has been viewed as a fertile ground for political corruption, especially when there is evidence of "abuse of public office for private gains" (e.g., Kaufmann and Vicente, 2011). As a result, anti-corruption policies have become a central component of development strategies in many countries and the World Bank alone has supported more than 600 anti-corruption programs since 1996 (Banerjee et al, 2012).

Research on corruption faces important theoretical and empirical challenges. On the theoretical side there is a need to go beyond the classical understanding of corruption as a generic form of moral hazard in organizations and analyze corruptive practices in different underlying environments (e.g., Banerjee et al., 2012). ${ }^{1}$ On the empirical side the most important issue is one of measurement as corruption is illicit and secretive by nature. We contribute to both theory and empirical evidence in this area.

In terms of theory, we build on Bhattacharyya and Hodler (2010) and present a model of corruption as a game between the elites (politicians) and the population, where the quality of democratic institutions plays an important part in punishing corrupt elites. Our model predicts that when corruption is not penalized because of poor political institutions, the level of corruption will increase. In our empirical work, we use unique panel data on firms to test the implication of this prediction, namely whether appointing politically connected individuals to the supervisory boards of directors of firms has a negative effect on the productive efficiency of these firms,

Our paper relates to several studies documenting connections between firms and politicians. Faccio (2006) for instance finds corporate political connections to be relatively widespread, more evident among

\footnotetext{
1 The term "environment" refers to the nature of monitoring and punishments, as well as to economic decisions in which the bureaucrats participate (Banerjee et al., 2012).
} 
larger firms and particularly common in countries that are perceived as being highly corrupt, imposing restrictions on foreign investment and having a less transparent system. ${ }^{2}$ She shows that corporate value increases significantly when a senior manager (CEO) enters politics and that there is no significant stock price effect detected when politicians are appointed to corporate boards. Faccio's (2006) findings are consistent with the hypothesis that politicians extract rents from companies they control (De Soto, 1989, Shleifer and Vishny, 1994) and that in equilibrium the cost of connections may offset their benefits. Desai and Olofsgard (2011) extend this notion by presenting a simple model in which politicians require firms to provide goods of political value for economic privileges ("elite exchange"). Based on the World Bank's Enterprise Surveys of approximately 8,000 firms in 40 countries, they are able to show that "privileged" firms are rewarded with improved business environment (lower administrative and regulatory barriers, greater pricing power, and easier access to credit). But these firms also provide politically valuable benefits to politicians through higher employment, bloated payrolls and greater tax payments. These "privileged" firms are found to be worse performers than their non-influential counterparts. Finally, Kaufmann and Vicente (2011) develop a theoretical model where corruption is endogenized and population has a credible threat of insurrection. They test the model on a dataset of 104 countries, suggesting that a lack of internal incentives for the political elite is the force causing the emergence of corruption.

While the existing studies contribute in important ways to our understanding of connections between firms and politicians, none provides detailed measures of "costs" of political connections in terms of lower productivity in a dynamic panel setting over a substantial period of time, using a large sample of firms. We are able to bridge this gap.

We focus our analysis on the effect of politically connected supervisory board members on total factor productivity of firms that they supervise. In addition, we are able to examine the performance effects of the composition of the supervisory boards in terms of gender - governance issue that is of considerable interest from both an academic and policy standpoint.

Slovenia is an interesting country-case in which to study the evolution of political corruption and its effect on firms' productivity over time. The country went through a relatively successful transition from communism to a market economy in the 1990s and it entered the European Union in 2003 after adopting the European institutional framework and satisfying the Maastricht criteria for entering the European Monetary Union (EMU). However, Slovenia has also been characterized by widespread political

\footnotetext{
${ }^{2}$ Faccio (2006) assembled a database of 20,202 publicly traded firms in 47 countries. She identified a firm to be politically connected if at least one of its large shareholders (controlling more than 10 percent of voting shares) or one of its top officers (CEO, president or vice-president) was a member of parliament, minister, or a person closely related to a top politician or political party. Slightly less than 3 percent of firms in the total sample were identified as being politically connected. However, there is a high cross country variation. In Russia, for example, 86.75 percent of the market capitalization was represented by political connected firms.
} 
corruption, underdeveloped democratic institutions and a continuation of high degree of state ownership in many firms. As such, it was unusually severely affected by the recent financial and economic crisis.

At the start of privatization in the 1990s, ninety five percent of Slovenia's GDP was produced by socially owned firms. Although one of the main goals of privatization was to find strategic owners who would bring know-how and new investment into the privatized firms, government eventually kept an important ownership stake through state investment funds. ${ }^{3}$ Moreover, firms in important sectors such as energy production and distribution, utilities, banking, and insurance remained state owned. ${ }^{4}$ Anecdotal evidence suggests that the appointment of supervisory board members in (semi-) state owned firms has often been based on political rather than professional criteria and international organizations have increasingly criticized Slovenia for maintaining an inefficient system of corporate governance in these firms. However, as Slovenia's GDP growth averaged close to 5 percent in 2004-2008, the criticism was not taken seriously. The setting has thus lent itself to possible abuse of political power for private gain (political corruption).

In order to study the effects of political corruption on firms' performance, we have collected unique panel data on the supervisory board structure in 251 firms that represent an almost complete population of joint stock companies with more than 100 employees in Slovenia during the 2000-2010 period. In terms of capital, our sample represents 77 percent of the value of assets of all business entities in Slovenia in 2010. We have identified 3,668 individuals serving as members of the supervisory boards of these firms, with 24 percent of them being politically connected in the 2000-2010 period.

Combining individual characteristics of supervisory board members with the firms' balance sheet and income statement data enables us to contribute to the literature in several important ways. First, we build on Bhattacharyya and Hodler's (2010) theoretical model of corruption to generate a theoretical model that reflects the institutional setting of Slovenia. Second, to the best of our knowledge we are the first to test the effects of political corruption using detailed firm-level panel data. We find evidence of political corruption and show in Table A1 in the appendix that its trend is increasing rather than decreasing over time. Third, in terms of empirical methodology we control for pre-treatment conditions and generate results using the Blundell-Bond (2000) GMM panel data estimator.

The paper proceeds as follows. In the next section we present the theoretical model, while in the third section we discuss the institutional setting and empirical specification. In the fourth section we

\footnotetext{
${ }^{3}$ We describe the privatization process in more detail in chapter 3.

${ }^{4}$ The previous (Yugoslav) economic system of self-management was based on social ownership. The firms belonged to the society as a whole, but were managed by workers of self-managed enterprises on a principle one person one voice. See Prašnikar and Svejnar (1991) for details.
} 
describe the dataset and data collection process. In the fifth section we present our empirical results and in the last section we draw our conclusions.

\section{Theoretical Framework of Political Corruption}

Kaufmann and Vicente (2011) define corruption in a broad sense as a collusive agreement between some agents in the economy who are able to swap political power over time in order to capture private gains. The most direct example is a situation where politicians have connections to firms and both exploit these connections for mutual benefit. The benefit might take the form of a special legislation or donation for a political campaign. Exchanging favors may also take the form of an explicit switch in the "position chair" among the elite players.

A political economy model of corruption may also involve politicians interacting with a population that has the possibility of using political instruments to affect the welfare of the politicians. Kaufmann and Vicence (2011) for instance assume that the population can react to corruption by "insurrecting" - making the corrupt agents suffer a sufficiently high penalty. ${ }^{5}$

Our theoretical model incorporates this reasoning and builds on the theoretical model of Bhattacharyya and Hodler (2010) in order to capture relevant dimensions of political corruption. While keeping the skeleton of Bhattacharyya and Hodler's (2010) model intact, we depart from their model in two distinct ways. First, we assume that corruption decreases the private gains of production and therefore reduces private investment. ${ }^{6}$ Secondly, we allow for the response of the elite to be observable in a dynamic context.

We assume that there are three groups of players in the economy: the incumbent political elite (E) with incumbent president in power, a challenger in the form of "new" elite (NE) and the rest of the population. The incumbent and new elite groups are homogenous groups and may be of either a good type $\left(\theta_{\mathrm{G}}\right)$ with probability $\alpha$ or a bad type $\left(\theta_{\mathrm{B}}\right)$ with probability $1-\alpha$. There are two periods, 1 and 2 . In period 1 the incumbent elite $\mathrm{E}$ chooses its level of corruption $\mathrm{c}_{1}$. Based on the level of $\mathrm{c}_{1}$ the population at the end of period 1 supports either the incumbent or the new elite. The level of corruption in period 2 depends on

\footnotetext{
${ }^{5}$ In this context they treat legal corruption as arising when elite prefers to hide corruption from the population and the costs of hiding are so called investment in "legal barriers". Investment in legal barriers and "insurrections" crucially depends on accountability and initially inequality among population. It can be proved that in the case of low initial inequality the legal corruption arises in the case of low accountability. In this case the legal barriers arise every period as well. On the other hand in the same case of low initial inequality but high accountability (for example like in Scandinavian countries) legal corruption and legal barriers do not arise and economy stays in this equilibrium.

${ }^{6}$ For the sake of simplicity, we also exclude the concept of corruptive income based on natural resources. The resource income largely depends on a country's resource abundance and our our model is designed for a country that is not rich in natural resources.
} 
the choice of elite that has been elected at the end of period 1. We assume that the good elite always selects a lower level of corruption than the bad elite:

$\mathrm{c}\left(\theta_{\mathrm{B}}\right)>\mathrm{c}\left(\theta_{\mathrm{G}}\right)$.

The main source of income for all three groups of players is domestic production $A_{t}$ that is primarily determined by the individuals' labor-leisure choice and their decisions over tangible and intangible capital accumulation (Bhattacharyya and Hodler, 2010). Corruption lowers the private return on productive activities and hence also the individuals' level of investment. We assume that production $\mathrm{A}_{\mathrm{t}}$ is a continuous function of corruption $\mathrm{A}_{t}=\mathrm{A}\left(\mathrm{c}_{t}\right)$ with $\mathrm{A}^{\prime}\left(\mathrm{c}_{t}\right)<0$ and $\mathrm{A}^{\prime \prime}\left(\mathrm{c}_{t}\right)<0$.

Following Bhattacharyya and Hodler (2010), we define the payoffs of the three players as follows. The welfare of the population in period $t$ is

$\mathrm{W}_{\mathrm{t}}=\mathrm{W}\left(\mathrm{c}_{\mathrm{t}}\right)=\left(1-\mathrm{c}_{\mathrm{t}}\right) \mathrm{A}\left(\mathrm{c}_{\mathrm{t}}\right)$

The payoff of the incumbent elite $u_{t}$ depends positively on corruption revenues $\pi\left(c_{t}\right)=c_{t}{ }^{*} A_{t}$ and on people's welfare $\mathrm{W}\left(\mathrm{c}_{\mathrm{t}}\right):^{7}$

$\mathrm{u}_{\mathrm{t}}=\pi\left(\mathrm{c}_{\mathrm{t}}\right)+\theta \mathrm{W}\left(\mathrm{c}_{\mathrm{t}}\right)=\left(\mathrm{c}_{\mathrm{t}}+\theta\left(1-\mathrm{c}_{\mathrm{t}}\right)\right) \mathrm{A}\left(\mathrm{c}_{\mathrm{t}}\right)$

The challenging new elite is not in power in period $t$ and thus has utility equal to zero. An important novelty of the Bhattacharyya and Hodler (2010) model is the introduction of democratic institutions. The quality of institutions is given by comparing probability $\mathrm{p}$ of electing good politicians in the next period with probability q of not being able to replace incumbent elite with new elite if people do not support the incumbents anymore. We assume that $0 \leq \mathrm{q} \leq \mathrm{p} \leq 1$. The quality of democratic institutions is given by $\mathrm{D} \equiv$ p - q. Low values of D signal poor democratic institutions as people's vote has little impact on the probability that the new elite come to office. On the other hand, high D implies that the incumbents are likely to stay in the office only if the people want them to stay.

In order to find equilibrium in this two-stage dynamic game with imperfect information, one applies the principle of backward induction. Assume that the elite in power in period 2 has no strategic incentives

\footnotetext{
7 As noted by Bhattacharyya and Hodler (2010), there are different motives for why the incumbent elite also cares about people's welfare and the performance of the economy. First, the economic conditions in general determine the salary of the incumbent elite and, second, the status and influence of the elite in the international community depends on the welfare of citizens.
} 
(e.g., to be elected in the following period) and it simply chooses the level of corruption that maximizes its utility, given its type $\theta: u_{2}=u\left(c_{2} ; \theta\right)$. The good elite benefits more from being in office in the second period $\theta \mathrm{W}\left(\mathrm{c}_{\mathrm{t}}\right)$ as $\theta_{\mathrm{G}}>\theta_{\mathrm{B}}$. In general, the elite in office chooses $\mathrm{c}^{*}$ that maximizes (2):

$\mathrm{c}^{*} \equiv \operatorname{argmax}_{\mathrm{ct}} \mathrm{u}_{\mathrm{t}}\left(\mathrm{c}_{\mathrm{t}} ; \theta\right)=-\mathrm{A} / \mathrm{A}^{\prime}-\theta /(1-\theta)$

If the politicians in power are highly corrupt, $\theta$ is close to zero and the level of corruption depends on the ratio between production revenue and the marginal revenue from corruption. Corruption is always positive as $\mathrm{A}^{\prime}<0$ by definition. In choosing the level corruption, the elite compares the value of production at a given level of corruption to the marginal revenue of increasing corruption by one unit. If politicians are good, with $\theta$ being close to unity, the second term dominates and is negative if $\theta \leq 1$. As corruption cannot be negative, we assume that the good elite always chooses $\mathrm{c}^{*}=0$.

If the bad politicians are in power, their chosen level of corruption in period two is higher, the less they benefit from social welfare $(\mathrm{dc} * / \mathrm{d} \theta<0)$. In deciding whom to support at the end of period 1 , the people are aware that their welfare will be higher with good rather than bad politicians in office. In particular, the people will prefer the elite with higher $\theta$. They therefore support the incumbent elite only if they believe that it is good with a higher probability than the challenger, or $\mu\left(\theta_{\mathrm{E}} \mid \mathrm{c}_{1}\right)>\alpha$. In equilibrium, a bad incumbent doesn't get people's support if he plays $\mathrm{c}_{1}>0$. If he knows he will not get people's support at the end of period 1 , it is better for him to choose the level of corruption that maximizes $u_{1}\left(c_{1} ; \theta_{B}\right)$. His expected utility in both periods is therefore equal to

$\mathrm{V}\left(\mathrm{c}^{*} ; \theta_{\mathrm{B}}\right)=(1+\mathrm{q}) \mathrm{u}\left(\mathrm{c}^{*} ; \theta_{\mathrm{B}}\right)$

while his utility from choosing $\mathrm{c}_{1}=0$ and getting people's support is

$\mathrm{V}\left(0 ; \theta_{\mathrm{B}}\right)=\mathrm{u}\left(0 ; \theta_{\mathrm{B}}\right)+\mathrm{pu}\left(\mathrm{c}^{*} ; \theta_{\mathrm{B}}\right)$

Bad elite therefore chooses $\mathrm{c}_{1}\left(\theta_{\mathrm{B}}\right)=\mathrm{c}^{*}$ if $\mathrm{V}\left(\mathrm{c}^{*} ; \theta_{\mathrm{B}}\right)>\mathrm{V}\left(0 ; \theta_{\mathrm{B}}\right)$, or $\left.\mathrm{D}<\left(\mathrm{u}\left(\mathrm{c}^{*} ; \theta_{\mathrm{B}}\right)-\mathrm{u}\left(0 ; \theta_{\mathrm{B}}\right)\right) / \mathrm{u}\left(\mathrm{c}^{*} ; \theta_{\mathrm{B}}\right)\right)$, as shown by Bhattacharyya and Hodler $(2010)$. When $\left.\mathrm{D}<\left(\mathrm{u}\left(\mathrm{c}^{*} ; \theta_{\mathrm{B}}\right)-\mathrm{u}\left(0 ; \theta_{\mathrm{B}}\right)\right) / \mathrm{u}\left(\mathrm{c}^{*} ; \theta_{\mathrm{B}}\right)\right)$ then the bad elite also chooses no corruption.

An interesting case arises when we observe the elite's decisions in a dynamic context in the environment of Slovenian-type underdeveloped democratic institutions, as described in the next section. Improving political institutions and increasing the probability of replacing the corrupt elite increases the opportunity cost of being replaced and therefore makes corruption income less attractive as compared to 
other benefits of being in power. On the other hand, elites learn how the society treats the signal of corruption and they change their behavior accordingly, becoming either more or less corrupt. Increasing an elite's willingness for corruption (lowering $\theta$ ) the benefit of corruption increases, ceteris paribus:

$\mathrm{d}\left(\left(\mathrm{u}\left(\mathrm{c}^{*} ; \theta_{\mathrm{B}}\right)-\mathrm{u}\left(0 ; \theta_{\mathrm{B}}\right)\right) / \mathrm{u}\left(\mathrm{c}^{*} ; \theta_{\mathrm{B}}\right)\right) / \mathrm{d} \theta<0$.

Our model hence predicts that in the case when corruption is not penalized because of poor political institutions, we should expect the level of corruption to increase.

Due to its illicit nature, we measure corruption indirectly - by estimating productive efficiency of firms with different potential extent of political corruption. In the next section, we first highlight the development of Slovenian economic environment and then present our econometric model.

\section{The Institutional Setting and Empirical Specification of the Model}

\subsection{The Institutional and Policy Setting}

Slovenia is a post-communist country that entered the transition in the early 1990s. One of the most important tasks of economic policy was to carry out privatization. A major difference of opinion emerged between the so-called "left" (old) and "right" (emerging) elite about how to privatize social property. While the new elite advocated a revolutionary approach (first nationalizing completely the socially owned firms and then privatizing them through ten state-owned investment funds), the old elite was in favor of employee and managerial buy-outs. ${ }^{8}$ After lengthy discussions, a compromise was reached and the Parliament passed the Law on the Transformation of Social Property (1992) - an umbrella law for implementing other laws that followed. In this context, it is to be noted that Slovenia selected a transition strategy in which foreign capital didn't play a substantial part. ${ }^{9} \quad$ Privatization took place after 1995 when additional laws supplementing the core legislation were implemented. Most firms that were subject to the privatization law ${ }^{10}$ prepared their privatization plans between 1995 and 2000.

\footnotetext{
${ }^{8}$ In fact there was also a third model of privatization proposed by Ribnikar and Prašnikar that favors the idea of converting all assets of socially owned firms to preferential shares of retirement funds. New owners would invest funds into firms and gained the governance power. All three models are described in details in Prašnikar and Svejnar (1993).

${ }^{9}$ In 2002 Sandoz took over Lek, a pharmaceutical company that was one of the largest firms in Slovenia. Although this takeover worked well for the company, speculations that the existing management team reaped substantial rewards by trading on the basis of internal information have never been dispelled. A prevalent position taken by the politicians was not to privatize most successful Slovene companies to foreigners, if not necessary.

${ }^{10}$ The Law did not apply to enterprises providing special public services, banks and insurance companies, enterprises engaged in the organization of gambling, enterprises that were transformed under the Law on Cooperatives, enterprises that were transformed under the forestry legislation, and firms in the process of bankruptcy.
} 
The 1992 Privatization Law allocated 20 percent of a firm's shares to insiders (workers), 20 percent to the Development Fund which auctioned the shares to investment funds, 10 percent to the National Pension Fund, and 10 percent to the Restitution Fund. In addition, in each enterprise the workers' council or board of directors (if one existed) was empowered to allocate the remaining 40 percent of company shares for sales to insiders (workers) or outsiders (through a public tender). Based on the decision about the allocation of this remaining 40 percent of shares, firms can be classified as being privatized to insiders (the internal method) or outsiders (the external method). In 2000 the first phase of privatization was almost completed, with majority of ownership in the small and medium sized firms being in the hands of state funds, investment funds and insiders (managers and workers). In large firms, state funds and investment funds gained control over the decision making process as these firms (a) were too big to privatize substantial part of their capital to insiders and (b) had many small dispersed owners. ${ }^{11}$

The privatization process was relatively efficient in the small and medium sized firms. Many of them eventually bought the ownership stake of the other parties to the privatization process (the state and investment funds). Large firms, on the other hand, found themselves in a position where the state remained a powerful owner through the indirect ownership of the Funds. The politicians soon realized that a loophole in the privatization law enabled them to control the supervisory boards of these quasi-privatized large firms, thus allowing them to influence also the appointment of management boards.

In 2001 a managerial buy-out of a quasi-privatized BTC company took place, using as financing the cash-flow of the firm. This opened the way for other management teams in big firms to act in a similar way. Following the BTC example, most takeovers were initiated and implemented by managers who were appointed by the political elite or had close ties to it. This constituted a second wave of privatization (20042008) that resulted in a few successful cases, while some of the largest firms either ended up in bankruptcy with a high level of indebtedness or had their shares seized by the banks as the special purpose vehicles (SPVs) established for the leveraged management buyouts were unable to repay their accumulated loans. In the meantime, in firms with prevailing state ownership the political elites continued to appoint politically selected supervisory board members who in turn elected politically selected members of the management board. In view of the underdeveloped governance institutions, the politicians were not "punished" for the mis-management of these quasi-privatized firms.

After 2005 OECD started to warn Slovenia about inefficient management of firms with substantial state ownership. Because of this criticism and growing evidence about politically motivated appointment

\footnotetext{
${ }^{11}$ As reported by study of Domadenik, Prasnikar and Svejnar (2008) that analyzed ownership structure in 157 big and medium sized Slovene firms slightly more than one-half of those firms were privatized primarily to insiders. The average share ownership was 31 percent by insiders, 34 percent by state and investment funds, 21 percent by other firms and 13 percent by other owners (banks and direct state ownership).
} 
of supervisory board members, a new agency for capital investment management was formed to make appointment of board members transparent. However, anecdotal evidence and our firm-level information suggest that corporate governance in firms with state ownership remained the same. In 2011, under a new government, the agency was in fact liquidated.

\subsection{The empirical model}

We assume that the production function of an individual firm may be approximated by a Cobb-Douglas form in a standard way (e.g., Acemoglu, 2009 and Jones, 1998) as:

$Y_{i t}=A_{t} K_{i t}^{\alpha K} L_{i t}^{\alpha L}$,

where $Y_{i t}$ represents output of firm i in period t, $K_{t}$ and $L_{t}$ are capital and labor inputs, respectively, and $\mathrm{A}_{t}$ is the Hicks-neutral efficiency level, or total factor productivity (TFP), of firm $i$ in period $t$.

While $Y_{i t}, K_{i t}$ and $L_{i t}$ are observable (usually in terms of value rather than in quantities), $A_{i t}$ is unobservable and is usually inferred as a residual. ${ }^{12}$ The acceleration of productivity growth in the US in the mid-1990s has generated the "new economy" view and a source-of-growth model started to stress the potential importance of intangible investments and their capitalization over time. In this context, our test of whether the composition of a firm's supervisory board affects its TFP may be interpreted as a test of the effect of a corporate governance structure on the ability of firms to generate intangible investment. ${ }^{13}$

In order to make the methods of measuring capital and labor more symmetric and capture the quality of the workforce, we use the wage bill as a measure of $L_{i t}$. As argued for instance by Fox and Smeets (2011), the wage bill reflects the marginal product of labor better than does the number of employees. ${ }^{14}$

Expressing equation (6) in logs yields

$y_{i t}=\alpha_{0}+\alpha_{K} k_{i t}+\alpha_{L} l_{i t}+\xi_{\text {it }}+u_{i t}$,

where lower case letters correspond to the natural logarithms of variables in equation (6), while $\ln A_{i t}=\alpha_{0}$ $+\xi_{i t}+u_{i t}$. While $\alpha_{0}$ measures the mean efficiency level across all firms over time, $\xi_{\text {it }}$ and $u_{i t}$ capture producerspecific deviations from the mean -- $\xi_{\text {it }}$ refers to factors such as managerial ability and the composition of

\footnotetext{
12 This is Abramovitz's famous "measure of our ignorance."

${ }^{13}$ Intangible resources in countries with underdeveloped capital and financial markets crucially depend on the ability of firms to generate internal funds. This is especially the case in Slovenia, as shown by Domadenik, Prašnikar and Svejnar (2008).

14 The correlation between and individual's wage and productivity is high even when the markets are not perfectly competitive.
} 
the supervisory board that are observed by firm $i$ and are likely to affect its choices of inputs, while $u_{i t}$ is an i.i.d. component that captures factors that are unobserved by the firms and hence affect output but not the choice of inputs. It also represents a measurement error in output or errors due to functional form discrepancies. These deviations may be further separated into an observable (or at least predictable) and unobservable components.

The identification and estimation of production functions using data on inputs and output is among the oldest empirical problems in economics with a key challenge of identification arising from endogeneity of inputs (the transmission bias discussed for instance by Griliches and Mairesse, 1998). Dynamic GMM panel data models (e.g., Arellano and Bond, 1991, and Blundell and Bond, 2000) are among the most popular approaches to tackle the problem of endogeneity by exploiting instruments based on lagged input decisions of the firm. We use the Blundell-Bond approach and specify our model (6a) as a dynamic augmented production function in which different supervisory board structures - contained in the $\xi_{\text {it }}$ term in equation (6a) above -- may affect TFP. The key explanatory variable with which we augment equation (6a) is the share of the supervisory board members who are politically connected and who are the focus of our analysis. In addition, we include as explanatory variables the shares of board members who are female and foreigners, the share of board members who live in the region of the firm, the size of the firm, and the annual shifts in the average TFP. The shares of women and foreigners are included in order to test whether greater board diversity in terms of gender and international composition affects the firm's efficiency. ${ }^{15}$ The share of board members who live in the region of the firm is included to assess the validity of the corporate social responsibility concept that local board members induce greater efficiency by bringing in a combination of a local sense of responsibility and local knowledge. Firm size is included to allow for productivity differences between small and large firms.

The empirical model is specified as follows:

$y_{i t}=\alpha_{0}+\alpha_{1} y_{i t-1}+\alpha_{2} k_{i t}+\alpha_{3} k_{i t-1}+\alpha_{4} l_{i t}+\alpha_{5} l_{i t-1}+\alpha_{6}{ }^{*} * S B \_S T R U C T U R E_{i t}+\alpha_{8} * S I Z E i+\alpha_{8}{ }^{*} * Y E A R_{t}+u_{i t}$,

where SB_STRUCTURE is a vector representing the structure of the Supervisory Board (measured by the shares of the board members who are politically connected and females), SIZE is a dummy variable that takes on value of 1 when the firm has more than 250 workers (large firm) and zero when it has 100-250

\footnotetext{
${ }^{15}$ If gender discrimination exists, firm performance would be better off in cases of a more balanced recruitment policy for managers and supervisory board members. Empirical evidence is mixed, ranging from positive effects of diversity management (Carter et al., 2003, Singh and Vinnicombe, 2004, and Smith et al., 2006) to no effect at all (Kochan et al., 2003).
} 
workers (medium sized firm). YEAR is a vector of dummy variables capturing annual time effects, $\alpha$ 's denote parameters, and $u_{i t}$ is the error term.

We apply Blundell-Bond (2000) GMM system estimation method to annual 2000-2010 firm-level data and we supplement the instruments that are generated directly by the system specification with several additional instruments. The first set of additional instruments is related to the privatization process in the 1990s. Based on evidence from Prasnikar and Svejnar (2006) and Domadenik et al. (2008), we categorize the firms into four groups. The first two groups consist of "de-novo" firms being owned either by foreigners or domestic private owners, the third group refers to firms that were subject to privatization in the 1990s, and the fourth group is represented by firms that remained fully in state ownership (utilities, telecommunication and energy production and transmission). We anticipate that the initial ownership structure in the late 1990s is an important factor explaining input levels in the years that followed. The second set of instruments consists of the contemporaneous regional unemployment rate in the period of 2000-2010, lagged (1998 and 1999) number of employees, and the change in return on equity in 1999.

\section{The sample}

\subsection{The data collection process}

Our sample is drawn from the population of large and medium sized non-financial joint-stock companies and holdings that existed in Slovenia during the period 2000-2010. All the firms employed more than 100 employees and had either one or two-tier corporate governance system.

The data were obtained in three phases. First, we collected publicly available data about members of the supervisory boards from the Agency of the Republic of Slovenia for Public Legal Records and Related Services (AJPES). This database ought to contain the first and last name, board position, home address, and country of residence of members of all supervisory boards. In particular, we were able to collect complete data on 308 out of 384 firms that existed in the group of non-financial joint-stock companies and holdings. ${ }^{16}$ The resulting database covers 3,668 supervisory board members.

We complemented the official source of supervisory board members' identification with reliable sources published on the internet to obtain data about the board members' political affiliation and other

\footnotetext{
${ }^{16}$ Companies were not required to report names of supervisory board members before 2007, however, and we were hence able to gather complete information about supervisory board members in 308 firms. 155 of them operated in the tradable sector and 153 in the non-tradable sector. It is important to note at this point that of 308 companies that had a supervisory board and were used in the analysis 292 had its own supervisory board. Remaining 16 companies did not have its own supervisory board but were owned and controlled by parent company with a supervisory board. Thus, for these 16 companies supervisory board data from parent company was used as a proxy that determined how important business decisions were made. We assumed that political influence from the parent company was also present in the decision-making of the daughter company.
} 
personal characteristics. ${ }^{17}$ We started by scanning online election registers to match the names and addresses of political election candidates with information in our supervisory board database. For the matched individuals we enlarged our dataset with information about their political affiliation and year of birth.

In the third phase of data gathering we matched our database of supervisory board members with financial data from balance sheet and income statements for the 308 selected firms. After excluding firms with no balance sheets' data available ${ }^{18}$ we ended up with 251 firms. Our final data set is an unbalanced set of 251 firms with 2,712 firm-year observations on all members of the supervisory board and balance sheet and income statement records. For these firms we also collected balance sheet and income statement data for the period of 1996-1999 in order to use these lagged values as instrumental variables in our empirical model.

\subsection{Description of variables used in the empirical model}

In 2010 the 251 sampled firms accounted for 77 percent of fixed assets of all firms in Slovenia and on average employed 528 employees. In the 2000-2010 period an average supervisory board had 5.31 members, 18.9 percent of whom were women. Full 24.5 percent of supervisory board members in an average firm were politically affiliated.

Table 1: Supervisory board composition by period

\begin{tabular}{lcccccccc}
\hline & \multicolumn{2}{c}{$\mathbf{2 0 0 0 - 2 0 0 3}$} & \multicolumn{2}{c}{$\mathbf{2 0 0 4 - 2 0 0 8}$} & \multicolumn{2}{c}{$\mathbf{2 0 0 9 - 2 0 1 0}$} & \multicolumn{2}{c}{ 2000-2010 } \\
& Mean & SD & Mean & SD & Mean & SD & Mean & SD \\
\hline $\begin{array}{l}\text { Number of } \\
\text { supervisors }\end{array}$ & 5.673 & 2.150 & 5.247 & 2.081 & 4.803 & 2.023 & 5.319 & 2.118 \\
$\begin{array}{l}\text { Share of politically } \\
\text { affiliated members }\end{array}$ & 0.220 & 0.216 & 0.259 & 0.240 & 0.258 & 0.240 & 0.245 & 0.234 \\
$\begin{array}{l}\text { Share of female } \\
\text { members }\end{array}$ & 0.199 & 0.186 & 0.185 & 0.197 & 0.175 & 0.201 & 0.189 & 0.194 \\
\hline
\end{tabular}

\footnotetext{
${ }^{17}$ In particular, we have carefully checked if any supervisory board members had a political affiliation defined as being a candidate for a local and/or state-level elected position, member of a political party or continuously expressing public support for a given political party.

${ }^{18}$ From AJPES registry we were able to get balance sheet and income statement data for most of the companies except for companies facing compulsory settlement, companies in bankruptcy procedure and those companies that underwent significant organizational change that prevented us from making a consistent panel of financial data.
} 
Since the economy and the privatization process went through three important phases during 20002010, we carry out our analysis for the entire period, as well as in the context of these three phases. The first phase (2000-2003) is the post-privatization period after the first privatization. During this phase, most firms completed the restructuring envisioned by the 1992 Law on Privatization. This is also a period of high investment and various other restructuring activities documented by Domadenik et al. (2008). The second phase is the period of economic upturn that lasted from 2004 to 2008 and contains the start of the second phase of privatization that relied primarily on management buyouts. The third phase (2009-2010) corresponds to the recent financial and economic crisis. The three periods also approximate the country's political cycles, with a left-center coalition governing in the first period, a right-center coalition governing in the second period and a left-center coalition being in charge in the third period.

As may be calculated from Table 1, during the three periods firms on average reduced the number of supervisors by 15.3 percent. On the other hand, the share of politically connected members recorded an increase while the share of female appointees decreased during the period under study.

Based on ownership, we classify the firms in our sample as state owned firms, foreign owned firms, firms owned by a large domestic owner, management buy-out (MBO), internally owned firms, and firms with dispersed ownership (no single type of an owner having majority ownership). These ownership groups originate from the privatization process in Slovenia, as described in section 3. ${ }^{19}$ Approximately one-third of the sample (33.5 percent) consists of state owned firms, 11.2 percent is represented by foreign owned firms, 24.4 by internally owned and MBO firms, 13 percent by large domestic owners, and the rest (almost 18 percent) by dispersed owners.

Examining the prevalence of politically connected supervisory board members across types of firm ownership (Table 2), we find that state owned firms had the largest percentage of politically connected supervisory board members (ranging, on average, from 34.1 percent in the 2000-2003 period to 38.9 in the 2004-2008 period and 35.3 in the 2009-2010 period), while firms owned by large domestic owners on average had only 16 percent of politically connected supervisory board members. Politically connected supervisory board members were more common in internally owned and MBO firms (around 23 percent and 20 percent in all three periods, respectively), which is understandable since the political elite in Slovenia was connected with top management of firms that went through privatization. Not surprisingly, foreignowned firms had the lowest percentage of politically connected supervisory board members (on average only 13.1 percent in the first period, 8.2 percent in the second period and 7.5 percent in the third period).

\footnotetext{
${ }^{19}$ See also Bole et al. (2011) for details.
} 
Table 2: Share of politically affiliated supervisory board members by firm ownership

\begin{tabular}{lllllll}
\hline & \multicolumn{2}{c}{$\mathbf{2 0 0 0 - 2 0 0 3}$} & \multicolumn{2}{c}{ 2004-2008 } & \multicolumn{2}{c}{ 2009-2010 } \\
& Mean & SD & Mean & SD & Mean & SD \\
\hline State owned firms & 0.341 & 0.239 & 0.389 & 0.238 & 0.353 & 0.248 \\
Foreign owned firms & 0.131 & 0.212 & 0.082 & 0.180 & 0.075 & 0.138 \\
$\begin{array}{l}\text { Firms owned by a large } \\
\text { domestic owner }\end{array}$ & 0.152 & 0.210 & 0.172 & 0.228 & 0.160 & 0.189 \\
MBO & 0.179 & 0.184 & 0.191 & 0.165 & 0.225 & 0.174 \\
Internal ownership & 0.228 & 0.172 & 0.223 & 0.234 & 0.231 & 0.263 \\
Dispersed ownership & 0.169 & 0.193 & 0.177 & 0.200 & 0.171 & 0.197 \\
\hline
\end{tabular}

Differences in supervisory board structures can be seen also across industries (Appendix Table A1). On one hand, there are industries with a low average number of supervisors and low share of politically affiliated supervisors (e.g. IT, trade and manufacturing). The electricity sector and utilities, on the other hand, have the largest number of supervisors and a high share of them being politically affiliated with an upward trend in utilities. This finding suggests that it is of interest to examine the extent of political affiliation of board members and its productivity effects separately for firms in the non-tradable and tradable sectors. Firms in the non-tradable sector tend to operate in a less competitive setting and thus have higher potential rents than firms in the tradable sector who tend to compete more in the export markets, a feature that could bring about more legal corruption into the non-tradable sector.

Examining separately the data for companies in the tradable and non-tradable sectors (Table 3) shows that companies in the non-tradable sector indeed on average have a larger share of politically affiliated supervisory board members and also larger supervisory boards. Hence, our conjecture that political influence would be greater in the non-tradable sector where monopoly power tends to be greater is supported by the raw data. The board share of women is on average similar and declining over time in both sectors of firms.

Table 3: Supervisory board composition by period and tradable and non-tradable sector

\begin{tabular}{lllllllll}
\hline & \multicolumn{2}{c}{$\mathbf{2 0 0 0 - 2 0 0 3}$} & \multicolumn{2}{c}{$\mathbf{2 0 0 4 - 2 0 0 8}$} & \multicolumn{2}{c}{$\mathbf{2 0 0 9 - 2 0 1 0}$} & \multicolumn{2}{c}{$\mathbf{2 0 0 0 - 2 0 1 0}$} \\
& $\begin{array}{l}\text { Non- } \\
\text { tradable }\end{array}$ & Tradable & $\begin{array}{l}\text { Non- } \\
\text { tradable }\end{array}$ & Tradable & $\begin{array}{l}\text { Non- } \\
\text { tradable }\end{array}$ & Tradable & $\begin{array}{l}\text { Non- } \\
\text { tradable }\end{array}$ & Tradable \\
\hline $\begin{array}{l}\text { Number of } \\
\text { supervisors }\end{array}$ & 5.912 & 5.446 & 5.528 & 4.969 & 5.123 & 4.479 & 5.806 & 5.077 \\
$\begin{array}{l}\text { Share of politically } \\
\text { affiliated members }\end{array}$ & 0.268 & 0.174 & 0.313 & 0.205 & 0.287 & 0.229 & 0.282 & 0.205 \\
$\begin{array}{l}\text { Share of female } \\
\text { members }\end{array}$ & 0.202 & 0.197 & 0.185 & 0.186 & 0.171 & 0.180 & 0.169 & 0.191 \\
\hline
\end{tabular}


In our empirical analysis we use selected variables from the balance sheet and income statements: value added (VA) as a measure of output, labor cost (LC) as a measure of the labor input and tangible fixed assets (K) as a measure of capital. Value added is calculated as sales less the cost of goods, materials and services. All values are in 1996 prices. The average firm reported 21,744 € of value added per employee in the 2000-2010 period. The average value added per employee increased by 21 percent in 2004-2008 relative to 2000-2003 and fell slightly during the crisis period of 2009-2010. Labor costs per employee averaged $20,952 €$ over the entire period and increased by 34 percent in 2004-2008 over 2000-2003. During the crisis years of 2009-2010, labor costs per employee followed an increasing pattern mostly due to an increase in the minimum wage by 25 percent in 2010. The number of employees increased by a mere 7 percent in the second period followed by a decrease of 3.6 percent in the third period.

Table 4: Selected balance sheet and income statement variables for sampled firms by period

\begin{tabular}{|c|c|c|c|c|c|c|c|c|}
\hline & \multicolumn{2}{|c|}{$2000-2003$} & \multicolumn{2}{|c|}{$2004-2008$} & \multicolumn{2}{|c|}{$2009-2010$} & \multicolumn{2}{|c|}{$2000-2010$} \\
\hline & Mean & SD & Mean & SD & Mean & SD & Mean & SD \\
\hline Employees & 521.45 & 838.53 & 558.30 & 1059.6 & 537.82 & 1058.8 & 541.36 & 985.36 \\
\hline $\begin{array}{l}\text { Value added (in mio } \\
€ \text { ) }\end{array}$ & 8.92 & 16.3 & 11.00 & 21.70 & 10.90 & 23.30 & 10.20 & 20.30 \\
\hline $\begin{array}{l}\text { Labor costs (in mio } \\
€)\end{array}$ & 5.35 & 9.35 & 6.36 & 11.90 & 6.29 & 11.80 & 5.98 & 11.00 \\
\hline $\begin{array}{l}\text { Value added per } \\
\text { employee (in } 1000 €)\end{array}$ & 19.23 & 28.19 & 23.25 & 38.60 & 22.89 & 36.23 & 21.74 & 34.79 \\
\hline $\begin{array}{l}\text { Labor costs per } \\
\text { employee (in } 1000 €)\end{array}$ & 16.65 & 6.50 & 22.42 & 9.74 & 25.79 & 10.46 & 20.95 & 9.50 \\
\hline $\begin{array}{l}\text { Fixed assets (in mio } \\
€ \text { ) }\end{array}$ & 35.90 & 135.00 & 36.40 & 165.00 & 39.00 & 185.00 & 36.70 & 159.00 \\
\hline
\end{tabular}

In the next section we present the results of our empirical analysis.

\section{Empirical results}

\subsection{OLS and System GMM estimations}

In Table 5 we report the estimated parameters of the augmented dynamic production function (7), while in Table 6 we present the corresponding short run and long run elasticities. The (robust Huber) OLS and System GMM specifications yield relatively similar results, with the preferred GMM estimates being statistically more significant. The estimated coefficient on lagged value added is large and statistically 
significant, suggesting that there is a high degree of persistence in value added over time. The short term elasticity of value added with respect to labor cost is high and similar to the elasticity obtained for the long run. The elasticity of value added with respect to fixed assets is relatively low in the short run, but substantially higher in the long term. Firm size isn't found to have any effect on TFP. Note that we control for macroeconomic shocks by including year dummy variables.

Table 5: Estimates of production function coefficients

\begin{tabular}{|c|c|c|}
\hline Coefficients & $O L S$ & Blundell-Bond System GMM \\
\hline \multirow{2}{*}{ Value added ${ }_{t-1}$} & $0.814 * * *$ & $0.740 * * *$ \\
\hline & $(0.012)$ & $(0.068)$ \\
\hline \multirow[t]{2}{*}{ Labor $\operatorname{cost}_{\mathrm{t}}$} & $0.763 * * *$ & $0.802 * * *$ \\
\hline & $(0.031)$ & $(0.104)$ \\
\hline \multirow[t]{2}{*}{ Labor cost $\mathrm{t}_{\mathrm{t}-1}$} & $-0.596^{* * *}$ & $-0.584 * * *$ \\
\hline & $(0.032)$ & $(0.114)$ \\
\hline \multirow[t]{2}{*}{ Fixed assets $t_{t}$} & $0.056 * * *$ & $0.059 *$ \\
\hline & $(0.017)$ & $(0.031)$ \\
\hline \multirow[t]{2}{*}{ Fixed assets $\mathrm{t}_{-1}$} & -0.014 & 0.008 \\
\hline & $(0.017)$ & $(0.031)$ \\
\hline \multirow[t]{2}{*}{ Firm Size ${ }_{t}$} & $-0.032 *$ & -0.007 \\
\hline & $(0.017)$ & $(0.041)$ \\
\hline \multicolumn{3}{|c|}{ Supervisory board characteristics } \\
\hline Share of politically & 0.055 & -0.007 \\
\hline affiliated members $\mathrm{s}_{\mathrm{t}}$ & $(0.046)$ & $(0.060)$ \\
\hline \multirow{2}{*}{$\begin{array}{l}\text { Share of politically } \\
\text { affiliated memberst-1 }\end{array}$} & $-0.087 *$ & $-0.139 * * *$ \\
\hline & $(0.047)$ & $(0.053)$ \\
\hline \multirow[t]{2}{*}{ Share of women $\mathrm{w}_{\mathrm{t}}$} & -0.052 & -0.042 \\
\hline & $(0.050)$ & $(0.064)$ \\
\hline \multirow[t]{2}{*}{ Share of women $\mathrm{t}_{\mathrm{t}-1}$} & 0.074 & $0.116^{* *}$ \\
\hline & $(0.050)$ & $(0.056)$ \\
\hline YEAR DUMMIES & Yes & Yes \\
\hline \multirow[t]{2}{*}{ Constant } & $-0.299 * *$ & -0.346 \\
\hline & $(0.118)$ & $(0.332)$ \\
\hline $\mathrm{N}$ & 2430 & 2174 \\
\hline Adjusted R2 & 0.952 & - \\
\hline Hansen test (p-value) & - & 0.107 \\
\hline
\end{tabular}

Note: 1 . Standard errors are in parentheses.

3. $* * *, * *$ and $*$ denote statistically significant values at $1 \%, 5 \%$, and $10 \%$ on a two tail test, respectively. 
Turning to the effect of political connectedness of board members, in both the OLS and the BlundellBond system GMM specifications there are strong negative effects of appointing politically affiliated members to the supervisory boards on total factor productivity of firms. While this TFP effect is not statistically significant in the short run, it is strong and negative in the long run. Using the GMM estimates in column 2, we find that increasing the share of politically affiliated appointees by 1 percentage point leads to a 0.139 percent average decrease in value added in the next year and to a 0.566 percent decrease in the long run, ceteris paribus. This result suggests that appointing a politically connected member to a 5-member supervisory board, and thus increasing political affiliation of board members by 20 percentage points, would decrease TFP by 2.78 percent on average in the next year and 11.32 percent in the long run. The negative long run effect of increasing the number of politically connected board members is also observed in the negative long run elasticity calculated from the GMM estimates in Table 6.

Increasing the share of women on supervisory boards has a statistically insignificant instantaneous effect on TFP, while the lagged effect is positive and statistically significant at the 5 percent confidence test level in the GMM specification and at an 14.5 percent level in the OLS model.

Table 6: Estimation of short and long term elasticities

\begin{tabular}{|l|l|l|}
\hline Coefficients & \multicolumn{1}{|c|}{ OLS } & \multicolumn{1}{|c|}{$\begin{array}{c}\text { Blundell-Bond } \\
\text { System GMM }\end{array}$} \\
\hline S-R Elasticity w.r.t. labor costs & $\begin{array}{l}0.763^{* * *} \\
(0.031)\end{array}$ & $\begin{array}{l}0.802^{* * *} \\
(0.104)\end{array}$ \\
\hline L-R Elasticity w.r.t. labor costs & $\begin{array}{l}0.901^{* * *} \\
(0.052)\end{array}$ & $\begin{array}{l}0.838^{* * *} \\
(0.090)\end{array}$ \\
\hline S-R Elasticity w.r.t. fixed assets & $0.056^{* * *}$ & $0.059^{* *}$ \\
& $(0.017)$ & $(0.031)$ \\
\hline L-R Elasticity w.r.t. fixed assets & 0.226 & $0.261^{* * *}$ \\
& $(0.027)$ & $(0.061)$ \\
\hline S-R Elasticity w.r.t. share of politically affiliated & 0.055 & -0.007 \\
members on supervisory board & $(0.046)$ & $(0.060)$ \\
\hline L-R Elasticity w.r.t. share of politically affiliated & -0.174 & $-0.566^{* *}$ \\
members on supervisory board & $(0.129)$ & $(0.274)$ \\
\hline S-R Elasticity w.r.t. share of women on supervisory & -0.052 & -0.042 \\
board & $(0.050)$ & $(0.064)$ \\
\hline L-R Elasticity w.r.t. share of women on supervisory & 0.118 & 0.284 \\
board & $(0.147)$ & $(0.326)$ \\
\hline
\end{tabular}

Note: 1. Standard errors are in parentheses.

2. $* * *, * *$ and $*$ denote statistically significant values at $1 \%, 5 \%$, and $10 \%$ on a two tail test, respectively. 


\subsection{Tradable v. non-tradable sectors}

As mentioned earlier, because firms in the non-tradable sector tend to operate in a less competitive setting and have higher potential rents and proportion of politically connected board members than firms in the tradable sector, it is worth examining whether legal corruption is stronger among firms in the non-tradable sector. In Table 7, we present the respective estimated coefficients for tradable and non-tradable firms, using the Blundell-Bond System GMM estimator.

As may be seen from Table 7, the share of politically affiliated members of the supervisory board has a significant negative effect on productivity in the long run in the non-tradable sector, while the effect is statistically insignificant in the tradable sector. In particular, increasing the number of politically connected board members by one percentage point in the non-tradable sector on average decreases TFP by 0.153 percent next year and 0.932 percent in the long run. This means that substituting a politically unconnected board member by a politically connected one on a five member board results in 3.1 percent lower TFP in the next year and 18.6 percent in the long run. Increasing the number of politically connected board members by one percentage point in the tradable sector on average decreases TFP by 0.137 percent next year but the effect diminishes in the long run. The results suggest that legal corruption is indeed stronger in the non-tradable sector.

Appointing a female supervisor on a five member board in the tradable sector results in a 4.18 percent lower productivity ${ }^{20}$ in the same year, but a positive and statistically significant effect of 4.54 percent with a lag of one year. Appointing female supervisory board members does not appear to have any significant effect in the non-tradable sector.

Table 7: Estimated production function coefficients for tradable and non-tradable sectors (Blundell - Bond System GMM)

\begin{tabular}{lll}
\hline Coefficients & Tradable sector & Non-tradable sector \\
\hline Value added ${ }_{\mathrm{t}-1}$ & $0.517^{* * *}$ & $0.826^{* * *}$ \\
& $(0.092)$ & $(0.050)$ \\
Labor cost $\mathrm{t}_{\mathrm{t}}$ & $0.730^{* * *}$ & $0.903^{* * *}$ \\
& $(0.172)$ & $(0.098)$ \\
Labor cost $\mathrm{t}_{\mathrm{t}-1}$ & $-0.328^{*}$ & $-0.746^{* * *}$ \\
& $(0.173)$ & $(0.105)$ \\
Fixed assets & 0.124 & $0.047^{*}$ \\
& $(0.075)$ & $(0.026)$ \\
Fixed assets & -0.012 & 0.005 \\
& $(0.064)$ & $(0.030)$
\end{tabular}

${ }^{20}$ The coefficient is statistically significant at 10 percent level. 


\begin{tabular}{|c|c|c|}
\hline Size $_{t}$ & $\begin{array}{l}-0.044 \\
(0.042)\end{array}$ & $\begin{array}{l}-0.022 \\
(0.052)\end{array}$ \\
\hline \multicolumn{3}{|c|}{ Supervisory board characteristics } \\
\hline Share of politically & 0.011 & -0.008 \\
\hline affiliated members $s_{t}$ & $(0.103)$ & $(0.062)$ \\
\hline Share of politically & $-0.137 *$ & $-0.153 * *$ \\
\hline affiliated members $\mathrm{t}_{\mathrm{t}-1}$ & $(0.080)$ & $(0.063)$ \\
\hline \multirow[t]{2}{*}{ Share of women ${ }_{t}$} & $-0.209 * *$ & 0.112 \\
\hline & $(0.066)$ & $(0.073)$ \\
\hline \multirow[t]{2}{*}{ Share of women $\mathrm{t}_{\mathrm{t}-1}$} & $0.227 * *$ & 0.021 \\
\hline & $(0.088)$ & $(0.060)$ \\
\hline YEAR DUMMIES & Yes & Yes \\
\hline \multirow[t]{2}{*}{ Constant } & -0.336 & -0.542 \\
\hline & $(0.317)$ & $(0.391)$ \\
\hline $\mathrm{N}$ & 1145 & 1028 \\
\hline Hansen test (p-value) & 0.427 & 0.753 \\
\hline
\end{tabular}

Note: 1. Standard errors are in parentheses.

$* * *, * *$ and $*$ denote statistically significant values at $1 \%, 5 \%$, and $10 \%$ on a two tail test, respectively.

Table 8: Estimates of short and long term elasticities in tradable and non-tradable sectors

\begin{tabular}{|l|l|l|}
\hline Coefficients & Tradable sector & Non-Tradable Sector \\
\hline S-R Elasticity w.r.t. labor costs & $0.730 * * *$ & $0.903 * * *$ \\
& $(0.172)$ & $(0.098)$ \\
\hline L-R Elasticity w.r.t. labor costs & $0.831^{* * *}$ & $0.906 * * *$ \\
& $(0.079)$ & $(0.163)$ \\
\hline S-R Elasticity w.r.t. fixed assets & 0.124 & $0.047 *$ \\
& $(0.075)$ & $(0.026)$ \\
\hline L-R Elasticity w.r.t. fixed assets & $0.231 * * *$ & $0.306 * * *$ \\
& $(0.059)$ & $(0.086)$ \\
\hline S-R Elasticity w.r.t. share of politically affiliated & 0.011 & -0.008 \\
members on supervisory board & $(0.103)$ & $(0.062)$ \\
\hline L-R Elasticity w.r.t. share of politically affiliated & -0.259 & $-0.932 * *$ \\
members on supervisory board & $(0.217)$ & $(0.451)$ \\
\hline S-R Elasticity w.r.t. share of women on supervisory & $-0.209 * *$ & 0.112 \\
board & $(0.066)$ & $(0.073)$ \\
\hline L-R Elasticity w.r.t. share of women on supervisory & 0.038 & 0.772 \\
board & $(0.249)$ & $(0.494)$ \\
\hline
\end{tabular}

Note: 1. Standard errors are in parentheses.

2. $* * *, * *$ and $*$ denote statistically significant values at $1 \%, 5 \%$, and $10 \%$ on a two tail test, respectively. 


\section{Conclusions}

In this paper we present and test a theory of how political corruption affects corporate governance and performance of partially or fully state owned enterprises (SOEs). Our game theoretic model predicts that underdeveloped democratic institutions that do not punish political corruption result in political connectedness of firms that in turn has a negative effect on performance. Using firm-level panel data on virtually all medium-size and large industrial firms in Slovenia, we measure a firm's political connectedness by the share of politically connected individuals on its supervisory board. We show that a higher share of politically connected supervisory board members leads to lower total factor productivity of the firm, ceteris paribus.

We also examine the extent of political affiliation of board members and its productivity effects separately for firms in the non-tradable and tradable sectors. Firms in the non-tradable sector tend to operate in a less competitive setting and thus have higher potential rents than firms in the tradable sector who tend to compete more in the export markets, a feature that could bring about more legal corruption into the nontradable sector. Examining separately basic data for companies in the tradable and non-tradable sectors indicates that companies in the non-tradable sector indeed on average have a larger share of politically affiliated supervisory board members and also larger supervisory boards. Within the multiple regression framework, we show that a higher share of politically affiliated members of the supervisory board has a significant negative effect on productivity in the long run in the non-tradable sector, while the effect is statistically insignificant in the tradable sector. The results suggest that legal corruption is indeed stronger in the non-tradable sector.

Our estimates of the effect of women's presence of women on supervisory boards suggest that the effect on productivity is positive. Given the paucity of women on supervisory boards, our findings are important for the debate about the appropriate gender composition of these boards.

Our research provides important evidence about the effects of the prevalent form of political corruption that is found in many transition and emerging market economies. The political connectedness of firms that gives rise to this corruption will presumably be reduced as democratic institutions become stronger and able to punish corrupt behavior. Since this is a slow process, in the short term a superior solution may be carefully implemented privatization of the remaining SOEs. In young democracies with low political accountability and underdeveloped institutions, ongoing state ownership of many firms may represent more a curse than blessing. 


\section{Appendix}

Table A1: Supervisory board composition by period and industry

\begin{tabular}{|c|c|c|c|c|c|c|c|}
\hline $\begin{array}{l}\text { Period 1 } \\
(2000-2003)\end{array}$ & $\begin{array}{l}\text { Manu- } \\
\text { facturing }\end{array}$ & $\begin{array}{l}\text { Utili } \\
\text {-ties }\end{array}$ & $\begin{array}{l}\text { Electrici- } \\
\text { ty }\end{array}$ & Trade & IT & Transport & Other $^{21}$ \\
\hline $\begin{array}{l}\text { Number of } \\
\text { supervisors }\end{array}$ & 5.429 & $\begin{array}{l}5.59 \\
4\end{array}$ & 6.164 & 6.073 & 5.838 & 6.500 & 5.527 \\
\hline $\begin{array}{l}\text { Share of } \\
\text { politically } \\
\text { affiliated } \\
\text { members }\end{array}$ & 0.173 & $\begin{array}{l}0.25 \\
9\end{array}$ & 0.402 & 0.165 & 0.192 & 0.318 & 0.299 \\
\hline $\begin{array}{l}\text { Share of } \\
\text { female } \\
\text { members }\end{array}$ & 0.199 & $\begin{array}{l}0.18 \\
9\end{array}$ & 0.129 & 0.253 & 0.148 & 0.159 & 0.280 \\
\hline
\end{tabular}

\begin{tabular}{llllllll}
\hline $\begin{array}{l}\text { Period 2 } \\
(\mathbf{2 0 0 4 - 2 0 0 8 )})\end{array}$ & $\begin{array}{l}\text { Manu- } \\
\text { facturing }\end{array}$ & $\begin{array}{l}\text { Utili- } \\
\text { ties }\end{array}$ & $\begin{array}{l}\text { Electrici- } \\
\text { ty }\end{array}$ & Trade & IT & Transport & Other \\
\hline $\begin{array}{l}\text { Number of } \\
\text { supervisors }\end{array}$ & 4.971 & 5.882 & 5.753 & 5.870 & 5.115 & 5.200 & 5.431 \\
$\begin{array}{l}\text { Share of } \\
\text { politically } \\
\text { affiliated }\end{array}$ & 0.200 & 0.361 & 0.469 & 0.224 & 0.158 & 0.294 & 0.350 \\
$\begin{array}{l}\text { members } \\
\begin{array}{l}\text { Share of } \\
\text { female } \\
\text { members }\end{array}\end{array}$ & 0.187 & 0.188 & 0.107 & 0.204 & 0.081 & 0.112 & 0.341 \\
\hline
\end{tabular}

\begin{tabular}{llllllll}
\hline $\begin{array}{l}\text { Period 3 } \\
(\mathbf{2 0 0 9 - 2 0 1 0 )}\end{array}$ & $\begin{array}{l}\text { Manufa- } \\
\text { cturing }\end{array}$ & $\begin{array}{l}\text { Utiliti- } \\
\text { es }\end{array}$ & $\begin{array}{l}\text { Electrici- } \\
\text { ty }\end{array}$ & Trade & IT & Transport & Other \\
\hline $\begin{array}{l}\text { Number of } \\
\text { supervisors }\end{array}$ & 4.490 & 5.881 & 5.441 & 4.710 & 5.542 & 4.875 & 5.214 \\
$\begin{array}{l}\text { Share of } \\
\text { politically }\end{array}$ & 0.214 & 0.476 & 0.325 & 0.222 & 0.118 & 0.313 & 0.233 \\
$\begin{array}{l}\text { affiliated } \\
\text { members }\end{array}$ & & & & & & & \\
$\begin{array}{l}\text { Share of } \\
\text { female } \\
\text { members }\end{array}$ & 0.179 & 0.189 & 0.130 & 0.192 & 0.143 & 0.059 & 0.288 \\
\hline
\end{tabular}

${ }^{21}$ Industry sector other represents Real Estate, Medical Services, and Publishing. 


\section{References}

Acemoglu, D. (2009). When Does Labor Scarcity Encourage Innovation? NBER Working Papers 14809, National Bureau of Economic Research, Inc.

Agrawal, A. and Knoeber, C. R. (2001). Do Some Outside Directors Play a Political Role? Journal of Law and Economics, 44(1), 179-98.

Arellano, M. and Bond, S.R. (1991). Some Tests of Specification for Panel Data: Monte Carlo Evidence and an Application to Employment Equations. Review of Economic Studies, 58, 277-297.

Banerjee, A, Hanna, R. and Mullainathan, S. (2012). Corruption. MIT Working Paper Series, WP No. 1208 .

Bhattacharyya, S. and Hodler, R. (2010). Natural Resources, Democracy and Corruption. European Economic Review, 54, 608-621.

Blundell, R.W. and Bond, S.R. (2000). Initial Conditions and Moment Restrictions in Dynamic Panel Data Models. Journal of Econometrics, 87, 115- 143.

Bole, V., Prašnikar, J., and Trobec, D. (2010). Accumulated Financial Debt of Firms as an Obstacle to Firms' Investments. In Prasnikar (ed.), The Role of Intangible Assets in Exiting the Crisis, Daily Finance, $117-130$.

Carter, D.A., Simkins, B.J. and Simpson W.G. (2003). Corporate Governance, Board Diversity, and Firm Value. The Financial Review, 38, 33-53.

Corrado, C., Hulten, C. and Sichel, D. (2005). Measuring Capital and Technology: An Expanded Framework. In Corrado, et al. (eds.), Measuring Capital in the New Economy, National Bureau of Economic Research Studies in Income and Wealth volume 65, 11-45.

De Soto, H. (1989). The other path: The invisible revolution in the Third Worlds. New York: Harper and Row Publishers.

Desai, R.M. and Olofsgård A. (2011). The Costs of Political Influence: Firm-Level Evidence From Developing Countries. Quarterly Journal of Political Science: 6(2), 137-178.

Domadenik, P., Prašnikar, J., and Svejnar, J. (2008). Restructuring of Firms in Transition: Ownership, Institutions and Openness to Trade. Journal of International Business Studies 39(4), 725-746. 
Dombrovsky, V. (2008). Do Political Connections Matter? Firm-level Evidence from Latvia. SSERiga/BICEPS Working Paper.

Faccio, M. (2006). Politically Connected Firms. American Economic Review 96, 369- 386.

Fazzari, S., Hubbard, G. and Peterson B. (1996). Investment and Finance Reconsidered. Brookings Papers on Economic Activity, 141-195.

Filippini, M., Hrovatin, N., and Zorić, J. (2004). Efficiency and regulation of the Slovenian electricity distribution companies. Energy policy, 32(3), 335-344.

Fisman, R. (2001). Estimating the value of political connections. American Economic Review (4), 1095 1102.

Fox, J. T. and Smeets, V. (2011). Does Input Quality Drive Measured Differences in Firm Productivity? NBER Working Paper No. 16853.

Griliches, Z and Mairesse, J. (1998). Production Functions: the Search for Identification. In S. Strom (ed.), Essays in Honour of Ragnar Frisch. Econometric Society Monograph Series, Cambridge University Press, Cambridge.

Hausman, J. (1978). Specification Tests in Econometrics. Econometrica 46: 1251-1271.

Hermalin, B.E. and Weisbach, M.S. (2003). Boards of Directors and Endogenously Determined Institution: A Survey of the Economic Literature. Economic Policy Review, 9(1), 7-26.

Joecks, J., Pull, K. and Vetter, K. (2013). Gender Diversity in the Boardroom and Firm Performance: What Exactly Constitutes a “Critical Mass? Journal of Business Ethics, 118(1), 61-72.

Johnson, S. and Mitton, T. (2003). Cronyism and Capital Controls: Evidence from Malaysia. Journal of Financial Economics, 67, 351-382.

Jones, C.I. (1998). Introduction to Economic Growth, W.W. Norton \& Co., Inc., New York.

Kang, D. C. (2003). Transaction Costs and Crony Capitalism in East Asia. Comparative Politics, 35, 439458. 
Kaufmann, D., Vincente, P.C. (2011). Legal Corruption. Economics \& Politics, 23 (2), 195-219.

Khwaja, A. I. and Mian, A. (2005). Do Lenders Prefer Politically Connected Firms? Rent Seeking in an Emerging Financial Market. Quarterly Journal of Economics, (120), 1371-1411.

Kochan, T., Bezrukova, K., Ely, R., Jackson, S., Joshi, A., Jehn, K., Leonard, J., Levine, D. and Thomas, D. (2003). The Effects of Diversity on Business Performance: Report of the Diversity Network. Human Resource Management, 42 (1), 3-21.

Kroszner, R.S. and Stratmann, T. (1998). Interest-Group Competition and the Organization of Congress: Theory and Evidence from Financial Services' Political Action Committees. American Economic Review, 88(5), 1163-87.

Krueger, A.O. (1974). The Political Economy of the Rent-Seeking Society. American Economic Review, 64(3), $291-304$.

Levinsohn, J and Petrin, A. (2003). Estimating Production Function Using Inputs to Control for Unobservables. Review of Economic Studies 70, 317-341.

Olley, S. and Pakes, A. (1996). The Dynamics of Productivity in the Telecommunications Equipment Industry. Econometrica, 64, 1263-1298.

Olson, M. (1982). The rise and decline of nations. New Haven: Yale University Press.

Prašnikar, J. and Svejnar, J. (1991). Workers Participation in Management vs. Social Ownership and Government Policies: Yugoslav Lessons for Transforming Socialist Economies. Comparative Economic Studies, 4, 27-45.

Prašnikar, J., Svejnar, J., Mihajlek, D. and Prašnikar, V. (1994). A test of enterprise behaviour under Yugoslav labor management. Rev. econ. stat., 4, 728-741.

Prašnikar, J. and Gregorič, A. (2002). The Influence of Workers' Participation on the Power of Management in Transitional Countries. The Case of Slovenia. Annals of Public and Cooperative Economics. 73(2), 269297.

Singh, V. and Vinnicombe, S. (2004). Why so few women directors in top UK boardrooms? Evidence and theoretical explanations, Corporate Governance - An International Review, 12 (4), 479-488. 
Shleifer, A. and Vishny, R.W. (1994). Politicians and Firms. Quarterly Journal of Economics, 109(4), 9951025.

Smith, N., Smith, V. and Verner, M. (2006). Do Women in Top Management Affect Firm Performance? A Panel Study of 2500 Danish Firms. International Journal of Productivity and Performance Management, 55(7), 569-593.

Stigler, G.J. (1971). The Theory of Economic Regulation. The Bell Journal of Economics and Management, 2(1), 3-21.

Tullock, G. (1967). The Welfare Costs of Tariffs, Monopolies and Theft. Economic Inquiry, 5(3), 224232.

Vynoslavaska, O., McKinney, J. A., Moore, C. W., and Longenecker, J.G. (2005). Transition ethics: A comparison of Ukrainian and United States business professionals. Journal of Business Ethics, 61(3), 283299.

Wooldridge, J.M. (2009). On estimating firm-level production functions using proxy variables to control for unobservables. Economics Letters, 104(3), 112-114. 